\title{
E-Waste Management: Save Earth
}

\author{
Sarita Rathi \\ PhD, Research Scholar \\ Department of Management Studies \\ Amity University, Noida
}

\author{
Shyamalendu Niyogi, PhD \\ Professor \\ Department of Management Studies \\ Amity University, Noida
}

\begin{abstract}
Use of information and communication technology is becoming popular with time as this technology is coming with a lot of lavishness so people are demanding more of it. Electronic items have taken a status symbol in our lives. In India rich class is using up to date devices like cell phones, laptops, computers, microwave ovens, fridge, televisions etc and then pass it on to the poor class. There is no proper way for disposal or recycling of these items. This paper discuses about the increasing problem of e-waste in India, existing technologies and policies for its management, challenges to implement e-waste and then finally after giving some suggestions for reducing e-waste the paper will conclude itself by saying save earth.
\end{abstract}

\section{Keywords}

E-waste, Recycling, Reuse, Refurbish

\section{INTRODUCTION}

Waste generated by electronic equipments as computers, radio, tv, phones, printers, fax and photocopy machines is called e-waste; computer has various components like flip flops, memory chips, motherboard and compact discs which create e-waste if not recycled properly. With time computer industry is growing at a high speed. Organizations are competing to provide cheaper and compatible systems to the users according to their requirements. It is making the world digital, however, this is the time to consider its counter effects as well. Because of high competition in every six months new technology replaces the existing one so people purchase updated technology computers. This is increasing the e-waste problem in society. [1]Now a day every organization is familiar with the term e-waste. Simply e-waste is the equipments which are not in use now because of one reason or another like may be their life has expired or user stopped to use them for some other reason. These equipments are harmful, pernicious, hazardous and risky for the environment if not disposed-off properly. People must be taught about the after effects of these equipments on the environment to control e-waste. [2]

Articles of electrical and electronic equipment (EEE) that are not disposed-off by the user and aid to waste are known as ewaste. As per UNEP, each year approximately 20 to 50 million tons e-waste is being generated. It is being predicted that this amount will double itself in the coming decade. Globally e-waste is increasing more as compare to any other type of municipal waste. As the technology is growing with time so proportion of e-waste is increasing more speedily because people are being more technical. Shorter life cycle of electronic products is accelerating e-waste. [3]

\section{CARBON FOOT PRINTS}

There are three levels of toxic emissions:

1. Primary emissions: Dangerous chemicals that are enclosed in e-waste like lead, mercury, arsenic, polychlorinated biphenyls (PCBs) etc.

2. Secondary emissions: Perilous response products of e-waste substances as a result of improper treatment like dioxins, furans or plastics formed by flame retardants.

3. Tertiary emissions: Unsafe substances that are worn for recycling like cyanide, mercury etc. [4]

\section{MINING OF NATURAL RESOURCES}

Natural resources are limited so their use should be smart and sustainable. Overexploitation of metals through mining for manufacturing products is increasing. So metal are becoming rare and expensive. This over use of mines is inviting pernicious effects for forests, plants, animals and all living species. If it will not be controlled than dooms day will happen soon. [5]

Crushing, shredding, or processing e-waste can amplify the in-place density of the waste, thus escalating the ability of the cell. Improved capacity lessens the lifecycle cost of disposal. On the other hand, shredding or crushing the waste may make future healing for advantageous recycle more costly.

Furthermore, it may reduce the value of the land filled ewaste, rendering some potentially reusable materials unfeasible. However, introducing large bulky unprocessed ewaste into the cell could result in a squat waste density and thus a very huge volume of disposal capacity per unit mass of waste, ensuing in a lifecycle a waste disposal cost that exceeds any recovery worth for the projected future. [6] 


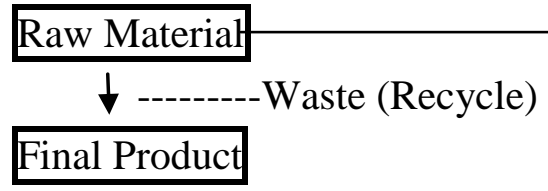

(Laptops, PC computers, mobiles, TVs,

Communication equipments and house-held devices)

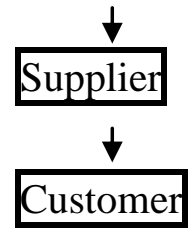

(Industry, education, healthcare and medicine, Communications, Security, information systems, Agriculture and food Industry, trading, military, Entertainment, services, and other fields)

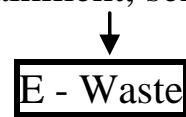

(Toxic heavy metals including arsenic, antimony, Lead, mercury, nickel and zinc)
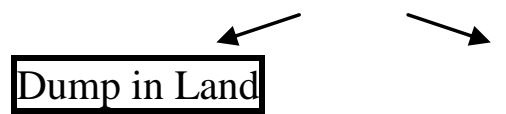

Recycle/Reuse (Raw Material)

(Causes soil, water and air pollution)

\section{POST CONSUMPTION EFFECTS}

India still not has any precise legislation for e-waste management and its disposal. Though there is some legislation on Hazardous Waste (HW) management from 1989 and these get updated time to time in 2000 and 2003, which obliquely speak about e-waste management and disposal.

These legislations are based on the provisions of the Basel Convention, which later on adopted and modified by India in 1992, and brought a conclusion that there are 18 categories of waste which are perilous, dangerous and hazardous above a certain capacity. Even though in rule 1989 e-wastes are not mentioned but in its amendments it is stated that e-waste are hazardous and their import and export should be restricted. The data from Directorate General of Commercial Intelligence and Statistics (DGCIS) shows that even after these restrictions the waste has still come into country. [1] There should be proper laws for e-waste management as the after effects of ewaste consumption are very insidious. They can cause harmful and incurable diseases like cancer. Some of them are mentioned below:

- Enter in food chain - Through sea level these can enter in our food chain and can cause untreatable adverse effects.

- Harmful diseases - E-waste can cause diseases which are not treatable. This is slow poison and can lead to death.
- Pollute environment - If not recycled in a proper manner e-waste can pollute environment more than any other source.

\subsection{Existing policies \& regulations on e- waste}

- The WEEE Directive (Waste Electrical and Electronic Equipment) it introduces a collection scheme in 2003 so that customers and return their discarded items free of cost for recycling. [7] However India is not having any strict rule for e-waste that's why tons of ewaste is coming every year from India. [8]

- E market for e-waste - U.S. started a scheme that clients pay a deposit at time of purchase, an amount of which is then reimbursed when they return the article at the end-of-life. This deposit covers transportation and recycling cost of the product. [9]

\section{- Reduce, reuse, recycle methods}

- Reuse: The best way to save environment is to not build a new computer. This reduces the damaging effects to the environment by $40 \%$.

- Refurbishment/Upgrading: do not discard a computer rather update it with new technology or can use its old part to refurbish the new one. It will reduce the pernicious effects to humans by $61 \%$. 
- Recycling: when we will recycle a metal, it will help in generating a new metal. The process of recycling reduces injurious effects to humans by $51 \%$ and harmful to the environment by $14 \%$ [5].

\subsection{Challenges}

- To implement e-waste management in India there are several challenges. Indian government publically talked about e-waste management 1st time on 12th may 2011 and as a result e-waste regulations came into existence from 1st may 2012. Following challenges are there to execute e-waste management successfully in India.

- Lack of infrastructure: No infrastructure is available with the government to execute e-waste management.

- Deficiency of rules: Present e-waste management rules need to be rectified and modified as they are not based on current scenario like life of an EEE product, level of producers from large scale to small scale, repair process etc.

- Consumer awareness: Buyers should be told about eco friendly products and training of how to use a product and its life time. It's really tough to make people aware about environment friendly products in a developing country like India as user will prefer cheap products rather than eco friendly.

- Diversity: India has diverse economic classes people. Equipment move from higher class to lower class from second hand to third hand. For a poor person, money matters more than environment.

- Why to dispose-off free of cost: In European countries there are collection centers which collect obsolete products from people to reduce e-waste however in India people are not willing to give even obsolete products free of cost to someone else.

- Additional financial burden: In a country like India this is an additional financial burden on the producers to collect and recycle products.

- Life of a product: In India life of a product is not fixed as people get their products repaired time to time even after they start polluting environment and more on that the shopkeeper who repair these products generate ewaste from the repaired parts. So repair shops should also be included in e-waste management. [10]

\subsection{Suggestions for e-waste management}

According to a survey done by Consumer Reports Online subscribers half of the respondents had replaced their cell phones within two years while rests are still having the same phone. After purchasing the new items customers are not able to decide what to do with the old one. Most of them are not willing to recycle or discard the items that are still working. [11] So government should make some alluring policies to manage e-waste. Here are some suggestions:
- Re sale e-products: Like in Japan Secondhand electronics products are collected from houses, business users and then sold to exporters. Exported equipments are like CRT color Televisions, fridge, washing machines, room heaters, air conditioners, audio equipment; play stations, sewing machines etc. [12]

- Donate: Someone can donate their electronic machines to the needy ones if they are not of use for them. This will reduce the e-waste and simultaneously lessen the requirement of more e-products, which will help in less mining of metals from earth to make it more sustainable.

- Update: Instead of buying a new machine one can use update option also to cop up with the technology. Like if a user wants to increase the memory of its computer than can add more memory to the existing system or can update new software or hardware with the same machine.

- Recycle: Electronic products should be recycled properly to reduce e-waste for that organization should educate users about the life time of a product, its proper use and its disposal. There should be alluring policies to attract people towards e-waste management like Samsung launched a policy in which user can replace their old mobile phones with the new ones under some specific discount.

\section{CONCLUSION}

Various organizations are working on e-waste management and have invented new technologies like green computing, cloud computing, virtualization etc to control e-waste. Government is also making policies regarding the same. However it needs more attention as people in India are still no aware about this issue and its harmful effects on environment as well as human beings. So proper awareness should be advertised and policies should be made such that even poor class will get attracted towards recycling the products. Disposal techniques should be proposed by keeping in mind that old and recycled metals will generate new metals and their disposal do not create harm to the environment. It brings a conclusion that the aim should be to save earth.

\section{REFERENCES}

[1] J. Vasudev and B. Parthasarathy, "The post consumptive residues of information and communication technologies transnational E-waste flows and developmental dilemmas," 2007 Int. Conf. Inf. Commun. Technol. Dev. ICTD 2007, 2007.

[2] A. M. Adeola and M. Othman, "An overview of ICT waste management: Suggestions of best practices from developed countries to developing nations (Nigeria)," 7th Int. Conf. Networked Comput., pp. 109-115, 2011.

[3] Y. Ting, H. Mien, W. Feng, J. Low, and S. Choong, "Improving E-waste Recovery with Energy Efficiency Information of Products 2 The Methodology," pp. 1-6.

[4] T. Solving and E. Problems, "Controlling Computers and Electronics Waste: Toward Solving Environmental Problems," no. July, pp. 3-5, 2012.

[5] S. Devika, "Environmental Impact of Improper Disposal of Electronic Waste," pp. 29-31, 2010. 
[6] R. F. Kahhat and E. Kavazanjian, "Preliminary Feasibility Study on the Use of Mono-disposal Landfills for E-waste as Temporary Storage for Future Mining," 2005.

[7] J. Leijting, "The Benefits of e-waste recycling in The Netherlands," p. 4, 2011.

[8] S. Xavierscollege, T. N. State, and T. N. State, "ROADWAY FOR SUSTAINABLE DISPOSAL OF SCRAP COMPUTERS," pp. 1-12, 2011.

[9] R. Kahhat, J. Kim, and M. Xu, "E-Market for E-Waste," vol. 85287, p. 85287, 2007.
[10] M. Brannon, P. Graeter, D. Schwartz, and J. R. Santos, "Reducing Electronic Waste through the Development of an Adaptable Mobile Device," vol. 00, no. c, pp. 57-62, 2014.

[11] C. N. Cairns, "E-waste and the Consumer: Improving Options to Reduce, Reuse and Recycle," pp. 237-242, 2005.

[12] A. Yoshida, T. Tasaki, and A. Terazono, "Environmental Life-cycle Impacts and Benefits of Secondhand CRT TVs Exported from Japan to the Philippines," 1992. 